ISSN : 2615-1995, E-ISSN : 2615-0654

J. Madani., Vol. 1, No. 2, September 2018 (287 - 303)

(C)2018 Lembaga Kajian Demokrasi

MADANI

dan Pemberdayaan Masyarakat (LKD-PM)

\title{
PENGARUH FINANCIAL LEVERAGE, OPERATING LEVERAGE, DAN CURRENT RATIO TERHADAP RENTABILITAS (STUDI KASUS PADA PT. INDAH KIAT PULP AND PAPER TBK DI TANGERANG)
}

\author{
Supatmin \\ Fakultas Ekonomi, Universitas Pamulang \\ masmin1966@gmail.com
}

\begin{abstract}
Abstrak
Pengelolaan unit usaha perusahaan sudah semestinya memerlukan tambahan dana untukmengembangkan usahanya. Oleh karena itu, salah satu cara yang dilakukan oleh perusahaan dalam memenuhi kebutuhan dana adalah dengan financial leverage dan operating leverage. Penelitian ini bertujuan untuk mengetahui pengaruh Financial Leverage, Operating Leverage, dan Current Ratio terhadap Rentabilitas pada PT. Indah Kiat Pulp and Paper Tbk. Metode yang digunakan dalam penelitian ini menggunakan metode kuantitatif dengan menganalisis melalui perhitungan, menyajikan data berdasarkan variabel yang diteliti serta penjelasan perkembangan setiap variabel untuk menjawab rumusan masalah, dan pengolahan data dengan statistik guna menguji hipotesis. Alat analisis yang digunakan meliputi analisis deskriptif, uji asumsi klasik dan analisis statistik inferesial. Hasil penelitian ini diperoleh hasil bahwa secara parsial financial leverage, operating leverage, dan current ratio tidak mempengaruhi rentabilitas, tetapi secara bersama-sama ketiganya mempengaruhi rentabilitas.
\end{abstract}

Kata Kunci: Financial Laverage, Operating Laverage, Current Ratio dan Rentabilitas

\section{PENDAHULUAN}

\section{Latar Belakang}

Setiap perusahaan membutuhkan dana dalam menunjang jalannya aktifitas perusahaan, baik itu perusahaan manufaktur ataupun perusahaan dagang dan jasa. Dana dapat pengelolaan unit usaha perusahaan, seringkali perusahaan memerlukan tambahan dana dalam memperluas unit usahanya. Oleh karena itulah salah satu cara yang dilakukan oleh perusahaan dalam memenuhi kebutuhan dana adalah financial leverage dan operating leverage. diperoleh dari pemilik perusahaan maupun dari pihak luar perusahaan. Namun dalam

Konsep operating dan financial leverage adalah bermanfaat untuk analisis, perencanaan dan pengendalian keuangan. Dalam manajemen keuangan, Leverage adalah peng- gunaan assets dan sumber dana (sources of founds) oleh perusahaan yang memiliki biaya tetap (beban tetap) dengan maksud agar meningkatkan keuntungan potensial pemegang saham. Jika semua biaya bersifat variabel, maka akan memberikan kepastian bagi perusahaan dalam menghasilkan laba. Tapi karena sebagai biaya perusahaan bersifat biaya tetap, maka untuk menghasilkan laba diperlukan tingkat penjualan minimum tertentu.

Perusahaan menggunakan operating dan financial leverage dengan tujuan agar keuntungan yang diperoleh lebih besar daripada biaya assets dan sumber dananya, dengan demikian akan meningkatkan keuangan pemegang saham. Sebaliknya leverage juga meningkatkan variabilitas (risko) keuntungan, karena jika perusahaan ternyata mendapatkan keuntungan 
yang lebih rendah dari biaya tetapnya maka penggunaan leverage akan menurunkan keuntungan pemegang saham.

Menurut Sutrisno (2003:230) bahwa financial leverage terjadi akibat perusahaan menggunakan sumber dana dari hutang yang menyebabkan perusahaan harus menanggung beban tetap. Financial leverage mengukur pengaruh perubahan keuntungan terhadap perubahan pendapatan bagi pemegang saham. Sedangkan operating leverage terjadi karena perusahaan dalam beroperasi menggunakan aktiva tetap sehingga harus menanggung biaya tetap. Operating leverage mengukur perubahan pendapatan atau penjualan terhadap keuntungan operasi.

Sedangkan Current Ratio adalah perbandingan antara aktiva lancar dengan utang lancar. Rasio ini menunjukkan seberapa jauh tuntunan dari kreditor jangka pendek di penuhi oleh aktiva yang diperkirakan menjadi uang tunai dalam periode yang sama dengan jatuh tempo utang. Current ratio yang rendah biasanya dianggap menunjukkan terjadinya masalah dalam likuidasi, sebaliknya current ratio yang terlalu tinggi juga kurang bagus, karena menunjukkan banyaknya dana menganggur yang pada akhirnya dapat mengurangi kemampulabaan perusahaan (Sawir, 2009:10). Sehingga besar kecilnya current ratio harus disesuaikan dengan aturan atau keputusan dari perusahaan itu sendiri serta sesuai kaidahkaidah pengelolaan keuangan.

Berkaitan dengan pentingnya masalah financial leverage dan operating leverage, maka hal ini perlu diperhatikan oleh perusahaan PT. Indah Kiat Pulp and Paper tbk di Tangerang saat ini adalah laba usaha yang dicapai oleh perusahaan mengalami penurunan faktor yang menyebabkan adanya penurunan laba usaha sebelum beban usaha yang dikeluarkan oleh perusahaan relatif meningkat untuk setiap tahun.

Berdasarkan uraian pada latar belakang yang dikemukakan di atas, maka penulis tertarik untuk melakukan penelitian dengan memilih judul : "Analisis Pengaruh Financial Leverage, Operating Laverage dan Current Ratio Terhadap Rentabilitas Perusahaan Pada PT. Indah Kiat Pulp and Paper Tbk di Tangerang“.

\section{Pembatasan Masalah}

Dengan keterbatasan peneliti dan agar lebih dimengerti serta memudahkan maka penelitian inipenulis memberikan batasan-batasan untuk memfokuskan permasalahan yang akan diteliti, yaitu mengenai Financial Leverage, Operating Leverage, Current ratio dan Rentabilitas pada PT. Indah Kiat Pulp and Paper Tbk dengan data laporan keuangan periode tahun 2011-2017 dengan cara melakukan penyebaran kuesioner kepada karyawan.

\section{Perumusan Masalah}

Berdasarkan identifikasi dan pembatasan masalah di atas, maka untuk mencegah terjadinya kerancuan dalam pembahasan, perlu penulis berikan suatu perumusan masalah sebagai berikut :

1. Apakah terdapat pengaruh secara parsial antara Financial Leverage terhadap Rentabilitas pada PT . Indah Kiat Pulp and Paper, Tbk?.

2. Apakah terdapat pengaruh secara parsial antara Operating Leverage terhadap Rentabilitas pada PT . Indah Kiat Pulp and Paper, Tbk?.

3. Apakah terdapat pengaruh secara parsial antara Current ratio terhadap Rentabilitas pada PT . Indah Kiat Pulp and Paper, Tbk?.

4. Apakah terdapat pengaruh secara simultan antara Financial Leverage, Operatinbg Leverage, dan Current Ratio terhadap Rentabilitas pada PT . Indah Kiat Pulp and Paper, Tbk?.

\section{Tujuan Penelitian}

Tujuan penelitian ini adalah :

1. Untuk mengetahui pengaruh secara parsial antara Financial Leverage terhadap Rentabilitas pada PT . Indah Kiat Pulp and Paper, Tbk?.

2. Untuk mengetahui pengaruh secara parsial antara Operating Leverage terhadap Rentabilitas pada PT . Indah Kiat Pulp and Paper, Tbk?.

3. Untuk mengetahui pengaruh secara parsial antara Current ratio terhadap Rentabilitas pada PT . Indah Kiat Pulp and Paper, Tbk?.

4. Untuk mengetahui pengaruh secara simultan antara Financial Leverage, Operating Leverage, dan Current Ratio terhadap Rentabilitas pada PT . Indah Kiat Pulp and Paper, Tbk?. 


\section{Tinjauan Pustaka}

\section{Manajemen Keuangan}

Manajemen keuangan memegang peranan yang sangat penting bagi perusahaan. Tugas manajer keuangan tidak hanya mencatat, membuat laporan, mengendalikan posisi kas, membayar tagihan, dan membayar dana. Akan tetapi, manajer keuangan juga harus menginvestasikan dana, mengatur kombinasi sumber dana yang optimal, serta pendistribusian keuntungan dalam rangka meningkatkan nilai perusahaan, investasi dana baik dilihat dari aspek laba, resiko usaha, maupun likuiditasnya. Hal ini mencakup keseluruhan aktivitas yang berkaitan dengan usaha mendapatkan dana (financing) dan menggunakan dana (investing) termasuk fungsi pemenuhan kebutuhan dana (pendanaan) sebagai usaha untuk memperoleh dana yang diperlukan dengan biaya yang minimal dan syarat-syarat yang paling menguntungkan.

Menurut Martono dan Agus Harjito (2010) mendefinisikan "Manajemen keuangan (financial management) merupakan segala aktivitas perusahaan yang berhubungan dengan bagaimana memperoleh dana, menggunakan dana, dan mengelola asset sesuai tujuan perusahaan secara menyeluruh".

Tujuan manajemen keuangan menurut Sutrisno (2010) yaitu 'Meningkatkan kemakmuran para pemegang saham atau pemilik". Sedangkan menurut Eugene F. Brigham dan Joel F. Houstom (2008) mengemukakan tujuan manajemen keuangan tercermin dalam 4 (empat) upaya sebuah perusahaan, yaitu sebagai berikut a) Laba yang maksimal b) Menjaga fleksibilitas perusahaan c) Resiko yang minimal dan d) Melakukan pengawasan aliran dana, dimaksudkan agar penggunaan dan pencarian dana dapat diketahui segera.

Fungsi Manajemen Keuangan menurut Agus Sartono (2001) adalah "Fungsi manajemen keuangan dapat diartikan sebagai manajemen dana baik yang berkaitan dengan pengalokasian dana dalam berbagai bentuk investasi secara efektif maupun usaha pengumpulan dana untuk pembiayaan investasi atau pembelanjaan secara efisien".

\section{Laporan Keuangan}

Menurut prinsip-prinsip akuntansi Indonesia, yang dimaksud Laporan keuangan adalah neraca dan perhitungan rugi-laba serta segala keterangan yang dimuat dalam lampirannya, antara lain laporan tentang sumber dan penggunaan dana.

Laporan keuangan merupakan produk akhir dari suatu proses akuntansi. Laporan keuangan inilah yang menjadi bahan informasi bagi para pemakainya sebagai salah satu bahan dalam proses pengambilan keputusan. Di samping sebagai informasi, laporan keuangan berperan sebagai pertanggungjawaban, laporan keuangan juga dapat menggambarkan sebagai indikator kesuksesan dalam suatu perusahaan dalam mencapai tujuannya (Harahap, 2002).

\section{Analisis Rasio Keuangan}

Analisis rasio keuangan merupakan metode untuk mengetahui hubungan dari pos-pos tertentu dalam neraca atau laba-rugi secara individu atau kombinasi dari kedua laporan tersebut (Munawir, 2007) yang menggambarkan suatu hubungan atau perlambangan antara suatu jumlah tertentu dengan jumlah lain, dan dengan menggunakan alat analisa berupa rasio yang akan menjelaskan atau menggambarkan kepada penganalisa baik atau buruknya keadaan posisi keuangan suatu perusahaan.

Menurut Robert Anggoro (2009) rasio keuangan dapat dikelompokkan menjadi lima jenis berdasarkan ruang lingkup atau tujuan yang ingin dicapai, yaitu:

a. Rasio Likuiditas (Liquidity Ratio)

Rasio ini menyatakan kemampuan perusahaan dalam jangka pendek untuk memenuhi kewajiban yang jatuh tempo.

b. Rasio Aktivitas (Activity Ratio)

Rasio ini menunjukkan kemampuan serta efisiensi perusahaan didalam memanfaatkan harta yang dimilikinya

c. Rasio Rentabilitas atau Profitabilitas (Profitability Ratio)

Rasio ini menunjukkan keberhasilan perusahaan didalam menghasilkan keuntungan.

d. Rasio Solvabilitas (Solvency Ratio)

Rasio ini menunjukkan kemampuan perusahaan untuk memenuhi kewajibannya. Rasio ini disebut juga leverage ratio.

e. Rasio Pasar (Market Ratio)

Rasio ini menunjukkan informasi penting perusahaan yang diungkapkan dalam basis perusahaan. 


\section{Financial Leverage}

Financial leverage menurut Martono dan Harjito (2008:301), mengemukakan bahwa : "Financial Leverage merupakan penggunaan dana dengan beban tetap dengan harapan atas penggunaan dana tersebut akan memperbesar pendapatan per lembar saham (earning per share, EPS)".

Masalah financial leverage baru timbul setelah perusahaan menggunakan dana dengan beban tetap, seperti halnya masalah operating leverage baru timbul setelah perusahaan dalam operasinya mempunyai biaya tetap. Perusahaan yang menggunakan dana dengan beban tetap dikatakan menghasilkan leverage yang menguntungkan (favorable financial leverage) atau efek yang positif kalau pendapatan yang diterima dari penggunaan dana tersebut lebih besar daripada beban tetap dari penggunaan dana itu.

Berdasarkan uraian tersebut di atas, maka dapat ditarik kesimpulan bahwa financial leverage merupakan usaha memperbesar efek perubahan atas laba sebelum pajak dan bunga/earning before interests and taxes (EBIT) terhadap earning per share (EPS) atau pendapatan per saham. Apabila dalam operating leverage, masalah fixed costs/aset tetap yang memengaruhi laba perusahaan dalam financial leverage adalah biaya modal tetap (fixed financial cost). Biaya modal tetap merupakan suatu bunga tetap (fixed interests) yang harus dibayar perusahaan sesuai dengan perjanjian kepada pemberi pinjaman (debt holdres) atau dividen atas saham preferen (preferred stockholders) sebelum pembagian pendapatan/ dividen kepada para pemegang saham umum (common stockholders).

Leverage financial, sebagaimana telah didefinisikan, menyangkut penggunaan dana yang diperoleh pada biaya tetap tertentu dengan harapan bisa meningkatkan bagian pemilik modal. Menurut Sinuraya (2008:130) bahwa: "Leverage yang menguntungkan terjadi apabila perusahaan memperoleh keuntungan lebih besar dari dana yang dibeli daripada biaya tetap penggunaan dana tersebut."

\section{Operating Laverage}

Financial leverage menurut Martono dan Harjito (2008:301), mengemukakan bahwa : "Financial Leverage merupakan penggunaan dana dengan beban tetap dengan harapan atas penggunaan dana tersebut akan memperbesar pendapatan per lembar saham (earning per share, EPS)".

Masalah operating leverage baru timbul setelah perusahaan dalam operasinya mempunyai biaya tetap. Perusahaan yang menggunakan dana dengan beban tetap dikatakan menghasilkan leverage yang menguntungkan (favorable financial leverage) atau efek yang positif kalau pendapatan yang diterima dari penggunaan dana tersebut lebih besar daripada beban tetap dari penggunaan dana itu.

\section{Current Ratio}

Menurut Martono dan Agus Harjito (2010:55) mengemukakan "Current ratio merupakan perbandingan antara aktiva lancar (current assets) dengan hutang lancar (current liabilities)". Aktiva lancar terdiri dari kas, suratsurat berharga, piutang dan persediaan. Hutang lancar terdiri dari hutang dagang, hutang wesel, hutang pajak, hutang gaji/upah, dan hutang jangka pendek lainnya.

Martono dan Agus Harjito (2010:55) mengemukakan "Current ratio yang tinggi memberikan indikasi jaminan yang baik bagi kreditor jangka pendek dalam arti setiap saat perusahaan memiliki kemampuan untuk melunasi kewajiban finansial jangka pendeknya, akan tetapi current ratio yang tinggi akan berpengaruh negatif terhadap kemampuan memperoleh laba, karena sebagian modal kerja tidak berputar atau mengalami pengangguran".

\section{Rentabilitas}

Salah satu ukuran utama keberhasilan manajemen dalam mengelola perusahaan adalah rentabilitas. Rentabilitas menurut Sutrisno (2003 : 18) bahwa : Rentabilitas adalah kemampuan perusahaan dalam menghasilkan keuntungan dengan semua modal yang bekerja didalamnya secara maksimal. Semua modal yang bekerja di dalam perusahaan adalah modal sendiri dan modal asing, oleh karena itu untuk mengukur besarnya rentabilitas (Sutrisno, 2003:5)

\section{Hipotesis Penelitian}

Hipotesis menurut Sugiyono (2014) adalah jawaban sementara terhadap rumusan masalah. Karena sifatnya masih sementara, maka perlu dibuktikan kebenarannya melalui data empirik 
yang terkumpul.

Adapun Hipotesis yang penulis ajukan adalah sebagai berikut:

H1 : Diduga terdapat pengaruh positif dan signifikan antara Financial Laveragetal Terhadap Rentabilitas pada PT. Indah Kiat Pulp and Paper, Tbk.

H2 : Diduga terdapat pengaruh positif dan signifikan antara Operating Laverage Terhadap Rentabilitas pada PT. Indah Kiat Pulp and Paper, Tbk.

H3 : Diduga terdapat pengaruh positif dan signifikan antara Current Ratio Terhadap Rentabilitas pada PT. Indah Kiat Pulp and Paper, Tbk.

H4 : Diduga terdapat pengaruh positif dan signifikan antara Financial Laverage dan Operating Laverage secara bersama-sama terhadap Rentabilitas pada PT. Indah Kiat Pulp and Paper, Tbk.

\section{METODOLOGI PENELITIAN}

\section{Tempat dan Waktu Penelitian}

Kegiatan penelitian dilakukan dengan cara menyebar angket/kuesioner pada karyawan PT. Indah Kiat Pulp and Paper, Tbk. yang beralamat di Jl. Raya Serpong Km. 8, Pakulonan, Serpong Utara, Tangerang, 15310 Banten-Indonesia untuk periode 2011-2017

\section{Populasi dan Sampel}

Populasi dalam penelitian ini adalah data berupa laporan keuangan pada PT. Indah Kiat Pulp and Paper, Tbk. Teknik yang digunakan dalam penarikan sampel menggunakan teknik non probability sampling. Non probability sampling. Adapun yang dijadikan sampel dalam penelitian ini adalah Laporan neraca dan Laba/ Rugi PT. Indah Kiat Pulp and Paper, Tbk di Tangerang periode 2011-2017.

\section{Variabel Penelitian}

Dalam penelitian ini terdapat tiga variabel, yaitu variabel independen, variabel dependen dan variabel moderating, seperti berikut:

1. Variabel bebas (independent variable) Variabel bebas yang dalam hubungannya dengan variabel lain bertindak sebagai penyebab atau yang mempengaruhi variabel dependen. Pada penelitian ini sebagai variabel independen yakni
Financial Leverage, Operating Leverage, dan Current Ratio. Variabel independen sering disebut sebagai predictor yang dilambangkan dengan $\mathrm{X}$.

2. Variabel terikat (dependent variable) Variabel yang tergantung dengan variabel lain, atau variabel yang dapat dipengaruhi oleh variabel lain. Sering disebut variabel respon di mana dalam penelitian ini adalah rentabilitas yang dilambangkan dengan $\mathrm{Y}$.

\section{Definisi Operasional Variabel}

Pengertian operasional variabel ini kemudian diuraikan menjadi indikator empiris yang meliputi :

\section{Finance Leverage $\left(\mathrm{X}_{1}\right)$}

Financial leverage adalah penggunaan sumber dana tertentu yang akan mengakibatkan beban tetap yang berupa biaya bunga. Sumber dana ini dapat berupa utang obligasi, kredit dan Bank dan sebagainya.

Financial leverage timbul jika suatu perusahaan mempergunakan utang jangka panjang dengan bunga tetap untuk membiayai investasinya, karena bunga yang sifatnya tetap ini, perusahaan tetap menanggung bunga terlepas apakah perusahaan memperoleh laba atau tidak. Pada saat laba perusahaan kecil, beban bunga tetap akan menurunkan hasil kepada pemegang saham. Sebaliknya biaya bunga adalah biaya yang dapat dikenakan pajak. Karenanya perusahaan mendapat subsidi atas beban bunga. Dalam kondisi seperti ini, maka subsidi atas bunga akan meningkatkan hasil kepada para pemegang saham (laba setelah pajak).

Dengan demikian, financial leverage mengukur tingkat kepekaan return untuk setiap saham (EPS) karena perubahan dari pendapatan sebelum bunga dan pajak (EBIT). Konsep operating dan financial leverage bermanfaat untuk analisis, perencanaan dan pengendalian keuangan. Dalam menajamen keuangan, leverage adalah penggunaan aktiva dan sumber dana oleh perusahaan yang memiliki biaya tetap (beban tetap) berarti sumber dana yang berasal dari pinjaman karena memiliki bunga sebagai beban tetap dengan maksud agar meningkatkan keuntungan potensial pemegang saham

\section{Operating Leverage $\left(\mathrm{X}_{2}\right)$}

Operating leverage merupakan penggunaan 
aktiva atau operasi perusahaan yang disertai dengan biaya tetap atau fixed cost. Konsep operating leverage menganalisis sejauh mana sales revenue dapat menutup biaya tetap dan biaya variabel.

Operating leverage adalah penggunaan sesuatu kekayaan atau aktiva tertentu yang akan mengakibatkan beban tetap bagi perusahaan seperti mesin-mesin, gedung dan sebagainya. Dalam hal ini beban tetapnya akan berupa biaya depresiasi. Operating leverage merupakan tingkat kepekaan pendapatan sebelum bunga dan pajak (Earning Before Interest and Taxes) karena perubahan dari volume penjualan.

\section{Current Ratio $\left(\mathrm{X}_{3}\right)$}

Rasio likuiditas merupakan gambaran kemampuan suatu perusahaan dalam memenuhi kewajiban jangka pendeknya secara lancar dan tepat waktu (Fahmi, 2012). Salah satu rasio likuiditas yang digunakan adalah Current Ratio/ Rasio Lancar. Rasio lancar adalah ukuran yang umum digunakan atas solvensi jangka pendek, kemampuan suatu perusahaan memenunuhi kebutuhan utang ketika jatuh tempo.

\section{4. $\quad$ Rentabilitas $(\mathrm{Y})$}

Rentabilitas adalah kemampuan perusahaan dalam menghasilkan laba, baik dengan menggunakan data eksternal maupun internal. Dari kedua pernyataan tersebut dapat diambil kesimpulan, bahwa rentabilitas adalah kemampuan suatu perusahaan dalam menghasilkan laba selama periode tertentu yang dinyatakan dalam prosentase. Rentabilitas suatu Perusahaan diukur dengan kesuksesan perusahaan dan kemampuan menggunakan aktiva yang Degree Operating Leverage (DOL)tif. Dengan demikian rentabilitas suatu perusahaan dapat diketahui dengan membandingkan antara laba yang diperoleh dalam suatu periode dengan jumlah aktiva atau modal koperasi tersebut. Salah satu ukuran utama keberhasilan manajemen dalam mengelola perusahaan adalah rentabilitas. Menurut Sutrisno (2003) bahwa: "Rentabilitas adalah kemampuan perusahaan dalam menghasilkan keuntungan dengan semua modal yang bekerja didalamnya.

\section{Metode Pengumpulan Data}

\section{Observasi}

Metode ini dipergunakan untuk menda- patkan data primer kuantitatif, dilakukan dengan cara penulis langsung mendatangi perusahaan pada bagian keuangan guna mendapatkan data berupa laporan keuangan perusahaan yaitu laporan neraca dan laporan rugi/ laba periode tahun 20011-2017, serta untuk memperoleh gambaran obyek yang diteliti yang nantinya akan dapat digunakan untuk tambahan dalam melakukan analisis.

\section{Wawancara}

Dalam penelitian ini untuk mendapatkan data primer kualitatif dengan metode wawancara, penulis datang ke kantor PT. Indah Kiat Pulp and Paper, Tbk. Untuk melakukan studi pendahuluan dengan teknik wawancara langsung dengan pihak yang berkompeten dalam perusahaan, mengenai obyek yang diteliti.

\section{Studi Pustaka}

Untuk medapatkan data sekunder penulis melakukan dengan cara penelahaan terhadap literature-literature berupa buku-buku kuliah dan data yang diperoleh dalam bentuk yang sudah jadi, sudah diolah oleh pihak lain biasanya dalam bentuk publikasi serta bahan-bahan yang berhubungan dengan masalah yang berkaitan dengan penelitian ini.

\section{Metode Analisis Data}

Metode analisis data yang digunakan dalam penelitan ini adalah:

\section{Uji Asumsi Klasik}

Uji asumsi klasik digunakan untuk mengetahui ketepatan sebuah data. Menurut Singgih Santoso (2011) berpendapat "Sebuah model regresi akan digunakan untuk melakukan peramalan, sebuah model yang baik adalah model dengan kesalahan peramalan yang seminimal mungkin. Karena itu, sebuah model sebelum digunakan seharusnya memenuhi beberapa asumsi, yang biasa disebut asumsi klasik". Dalam penelitian ini uji asumsi klasik yang digunakan adalah meliputi: uUji Normalitas, Uji Multikolinearitas, Uji Autokorelasi, dan Uji Heterokedastisitas

\section{a. Uji Normalitas}

Uji normalitas digunakan untuk menguji apakah dalam sebuah model regresi, variabel dependen, variabel independen, atau keduanya mempunyai distribusi normal atau tidak. 
Menurut Ghozali (2013) berpendapat "Model regresi yang baik adalah berdistribusi normal atau mendekati normal". Jadi uji normalitas bukan dilakukan pada masing-masing variabel tetapi pada nilai residualnya. Dengan demikian uji ini untuk memeriksa apakah data yang berasal dari populasi terdistribusi normal atau tidak. Uji normalitas dapat berpedoman pada uji Kolmogorov Smirnov dengan ketentuan sebagai berikut :

1). Jika nilai signifikansi $<0,05$ (taraf kepercayaan 95\%), maka data tidak berdistribusi normal.

2). Jika nilai signifikansi $>0,05$ (taraf kepercayaan 95\%), maka data berdistribusi normal.

\section{b. Uji Multikolinieritas}

Uji Multikoliniearitas ini bertujuan menguji apakah pada model regresi ditemukan adanya korelasi antar variabel independen. Menurut Ghozali (2013), berpendapat bahwa "Uji multikolinearitas bertujuan untuk menguji apakah pada model regresi ditemukan adanya korelasi antar variabel bebas (independen)". Model regresi yang baik seharusnya tidak terjadi korelasi di antara variabel independen. Jika variabel independen saling berkorelasi, maka variabel-variabel ini tidak ortogonal. Variabel ortogonal adalah variabel independen yang nilai korelasi antar sesama variabel independen sama dengan nol. Untuk mendeteksi ada tidaknya multikoliniearitas dalam model regresi dapat dilihat dari tolerance value atau Variance Inflation Factor (VIF) dengan ketentuan sebagai berikut:

1) Jika nilai nilai tolerance lebih $>$ dari 0.1 dan nilai variance inflation factor (VIF) $<$ dari 10, maka tidak terjadi multikolinieritas.

2) Jika nilai nilai tolerance lebih $<$ dari 0.1 dan nilai variance inflation factor (VIF) $>$ dari 10 , maka terjadi multikolinieritas.

\section{c. Uji Heteroskesdastisitas}

Menurut Ghozali (2013) "Uji heteroskedastisitas bertujuan untuk mengetahui apakah dalam model regresi terjadi ketidaksamaan varian dari suatu residual pengamatan ke pengamatan lain". Untuk mengetahui ada tidaknya heteroskedastisitas adalah dengan menggunakan uji scatter plot dengan melihat grafik antara nilai prediksi variabel terikat (ZPRED) dan nilai residualnya (SRESID) dengan ketentuan sebagai berikut :

1) Jika penyebaran titik-titik pada data scatter plot membentuk pola tertentu yang teratur seperti gelombang besar melebar, kemudian menyempit, atau dengan baik turun mengelompok menjadi satu, maka telah terjadi heteroskedastisitas.

2) Jika titik-titik menyebar diatas dan dibawah angka 0 pada sumbu $\mathrm{Y}$ tanpa membentuk pola tertentu, maka tidak terjadi problem heteroskedastisitas

\section{Analisis Deskriptif dan Verifikatif \\ a. Analisis Deskriptif}

Analisis dilakukan dengan menyajikan data, menganalisis melalui perhitungan, penjelasan perkembangan setiap variabel dan pengolahan data dengan statistik guna menguji hipotesis.

\section{b. Analisis Verivikatif}

Analisis kuatitatif adalah penelitian yang telah dilakukan untuk menilai kondisi dari nilai pengaruh, signifikansi pengaruh, dan kelayakan model. Menurut Sugiyono (2014) "Metode verifikatif merupakan penelitian yang bertujuan untuk mengetahui hubungan antara 2 (dua) variabel atau lebih. Dengan demikian dari hasil dari analisis ini akan memberikan jawaban awal dari kalimat tanya pada perumusan masalah : bagaimana pengaruh variabel independen terhadap variabel dependen secara parsial maupun secara simultan berdasarkan data yang ada. Dalam penelitian ini data yang dimaksud adalah data berupa laporan keuangan dari PT. Indah Kiat Pulp and Paper, Tbk periode 20011-2017 (7 tahun) yang sudah dibuat data panel. Adapun tahapan analisis yang dilakukan meliputi:

1) Analisis Regresi Linier Sederhana

Analisis regresi linier sederhana ini dalam penelitian ini dimaksudkan untuk menganalisis pengaruh secara parsial antara variabel Financial Laverage $\left(\mathrm{X}_{1}\right)$, Operating Laverage $\left(\mathrm{X}_{2}\right)$ dan Current Ratio $\left(\mathrm{X}_{3}\right)$ Terhadap Rentabilitas (Y) pada PT. Indah Kiat Pulp and Paper, Tbk.

2) Analisis Regresi Berganda

Di mana untuk mencapai tujuan penelitian yaitu menganalisis pengaruh Financial Laverage $\left(\mathrm{X}_{1}\right)$, Operating Laverage $\left(\mathrm{X}_{2}\right)$ dan 
Current Ratio $\left(\mathrm{X}_{3}\right)$ secara bersama-sama terhadap Rentabilitas (Y) pada PT. Indah Kiat Pulp and Paper, Tbk adalah dengan menggunakan analisis regresi berganda (Multiple regresional analisis).

3) Analisis Koefisien Korelasi

Analisis ini bertujuan untuk mengetahui tingkat keterhubungan atau pengaruh masing-masing variabel independen terhadap variabel dependennya baik secara parsial maupun secara simultan.

\section{4) Analisis Koefisien Determinasi}

Dalam penelitian ini untuk mengetahui berapa besar prosentase kontribusi dari variabel Financial Laverage $\left(\mathrm{X}_{1}\right)$, Operating Laverage $\left(\mathrm{X}_{2}\right)$ dan Current Ratio $\left(\mathrm{X}_{3}\right)$ terhadap Rentabilitas (Y) pada PT. Indah Kiat Pulp and Paper, Tbk, baik secara parsial maupun secara simultan.

5) Pengujian Hipotesis

Pengujian hipotesis dimaksudkan untuk menguji dugaan sementara yang dirumuskan dalam hipotesis berdasarkan data empiris. Dalam penelitian ini pengujian hipotesis dilakukan dengan uji t dan uji F. (a) Uji t (Parsial)

Uji t digunakan untuk menguji signifikansi variasi hubungan antar variabel $\mathrm{X}$ dan $\mathrm{Y}$, apakah variabel $\mathrm{X}_{1}, \mathrm{X}_{2}$ dan $\mathrm{X}_{3}$ benar-benar berpengaruh secara parsial terhadap variabel dependen.(Y).

(b) Uji F (Simultan)

Pengujian hipotesis simultan (Uji F) bertujuan untuk mengetahui pengaruh secara bersama-sama antara variabel variabel independen $\left(\mathrm{X}_{1}, \mathrm{X}_{2}\right.$ dan $\left.\mathrm{X}_{3}\right)$ terhadap variabel dependen $(\mathrm{Y})$.

\section{ANALISIS DAN PEMBAHASAN Analisis Deskriptif Variabel Penelitian}

Sesuai dengan tujuan analisis deskriptif yaitu untuk memberikan gambaran mengenai hasil penelitian secara umum, bagaimana karakteristik subyek penelitian sehubungan dengan variabel-variabel yang diteliti. Sebelum dilakukan analisis statistik terlebih dahulu dilakukan pengelompokan data dan menghitung presentase perkembangan (kenaikan dan penurunan) setiap tahunnya yang disajikan sebagai berikut:

\begin{tabular}{|c|c|c|c|c|c|c|c|c|}
\hline Tahun & EBIT & (\%) & EPS & (\%) & Pendapatan & (\%) & Hutang Lancar & (\%) \\
\hline 2010 & 25,650 & - & 0.001 & - & $1,885,300$ & - & $2,670,335$ & - \\
\hline 2011 & $(123,347)$ & $-580.88 \%$ & $(0.029)$ & $-2997.00 \%$ & $1,773,400$ & $-5.94 \%$ & $2,820,435$ & $5.62 \%$ \\
\hline 2012 & 73,381 & $-159.49 \%$ & 0.002 & $-108.22 \%$ & $2,509,631$ & $41.52 \%$ & $2,836,168$ & $0.56 \%$ \\
\hline 2013 & 22,940 & $-68.74 \%$ & 0.003 & $23.11 \%$ & $2,559,942$ & $2.00 \%$ & $2,907,676$ & $2.52 \%$ \\
\hline 2014 & 32,129 & $40.06 \%$ & 0.009 & $209.56 \%$ & $2,518,091$ & $-1.63 \%$ & $3,575,396$ & $22.96 \%$ \\
\hline 2015 & 206,906 & $543.99 \%$ & 0.040 & $345.53 \%$ & $2,651,473$ & $5.30 \%$ & $3,271,557$ & $-8.50 \%$ \\
\hline 2016 & 126,509 & $-38.86 \%$ & 0.023 & $-42.86 \%$ & $2,635,037$ & $-0.62 \%$ & $2,918,645$ & $-10.79 \%$ \\
\hline 2017 & 229,871 & $81.70 \%$ & 0.041 & $76.35 \%$ & $2,834,278$ & $7.56 \%$ & $2,935,591$ & $0.58 \%$ \\
\hline Avg.. & 74,255 & $-26.03 \%$ & 0.011 & $-356.22 \%$ & $2,420,894$ & $6.88 \%$ & $1,435,315$ & $14.27 \%$ \\
\hline
\end{tabular}

Berdasarkantabeldiatasperkembanganlaba bersih sebelum bunga dan pajak (EBIT) tahun 2010-2017 fulktuatif dengan rata-sata pertahun mencapai 74.255 dengan perkembangan minus $-26.03 \%$, hal ini dikarenakan kenaikan beban usaha yang kurang berimbang. Untuk Laba per lembar saham (EPS) juga fluktuatif rata-rata per tahun 0,001 dengan pertumbuhan minus $356,22 \%$. Untuk pendapatan setiap tahunnya fluktuatif cenderung mengalami kenaikan. Dan untuk hutang lancar juga diperoleh pertahuan dengan jumlah yang fluktuatif dengan kecende- rungan pertumbuhan sebesar $14,27 \%$.

\section{a. Variabel Degree Financing Leverage (DFL $\left(\mathrm{X}_{1}\right)$}

Berdasarkan data perkembangan EBIT, EPS dan pendapatan termin proyek maka diperoleh DFL untuk tahun 2011-2017, sebagai berikut : 


\begin{tabular}{|c|c|c|}
\hline \multirow{2}{*}{ Tahun } & \multicolumn{3}{|c|}{ Financial Leverage } \\
\cline { 2 - 3 } & $\begin{array}{c}\text { Hasil DFL } \\
\text { (Dalam Kali) }\end{array}$ & $\begin{array}{c}\text { DTL } \\
\text { (Dalam Kali) }\end{array}$ \\
\hline 2011 & 5,16 & 504,94 \\
\hline 2012 & 0,68 & $(2,61)$ \\
\hline 2013 & $(0,34)$ & 11,53 \\
\hline 2014 & 5,23 & $(128,18)$ \\
\hline 2015 & 0,64 & 65,23 \\
\hline 2016 & 1,10 & 69,14 \\
\hline 2017 & 0,93 & 10,10 \\
\hline Rata-rata & 1,92 & 75,74 \\
\hline \multicolumn{2}{|c}{} & Sumber: Data diolah \\
\hline
\end{tabular}

Tabel di atas yakni hasil perhitungan DFL untuk tahun 2011-2017 yang menunjukkan bahwa rata-rata DFL yang dicapai oleh perusahaan sebesar $1,92 x$ pertahun. Sedangkan untuk DTL diperoleh rata-rata per tahun sebesar $75,74 \mathrm{x}$.

\section{b. Variabel Degree Operating Leverage (DOL) $\left(\mathbf{X}_{2}\right)$}

Aspek permodalan yang menjadi titik pokok dalam penelitian ini adalah Degree Operating Leverage (DOL) yaitu perbandingan perubahan EBIT dengan penjualan, yang disajikan dalam tabel dibawah ini:

\begin{tabular}{|c|c|}
\hline \multicolumn{2}{|c|}{ Tabel 5. Hasil Perhitungan DOL } \\
\hline TAHUN & DEGREE OPERATING LEVERAGE (\%) \\
\hline 2011 & 97,87 \\
\hline 2012 & $(3,84)$ \\
\hline 2013 & $(34,29)$ \\
\hline 2014 & $(24,29)$ \\
\hline 2015 & 102,70 \\
\hline 2016 & 62,68 \\
\hline 2017 & 10,81 \\
\hline Rata-rata & 30,20 \\
\hline \multicolumn{2}{|c|}{} \\
\hline
\end{tabular}

Tabel di atas hasil perhitungan DOL untuk tahun 2011-2017 menunjukkan bahwa rata-rata DOL yang dicapai oleh perusahaan berfluktuasi dengan besaran rata-rata pertahun sebesar 30,20 kali. Namun besarnya DOL terendah dialami tahun 2013 yang minus sebesar $-34,29 \%$, penurunan ini disebabkan karena adanya peningkatan EBIT.

\section{c. Variabel Current Ratio (CR) $\left(\mathbf{X}_{3}\right)$}

Pengukuran rasioini merupakan rasio yang mengukur seberapa jauh aktiva lancar perusahaan bisa dipakai untuk memenuhi kewajiban lancarnya. Current ratio menunjukkan sejauh mana aktiva lancar menutupi kewajiban-kewajiban lancar. Adapun data hasil perhitungan disajikan pada tabel berikut ini:

\begin{tabular}{|c|c|}
\hline \multicolumn{2}{|c|}{ Tabel 5. Hasil Perhitungan CR } \\
CURRENT RATIO (\%)
\end{tabular}

Tabel di atas yakni hasil perhitungan current ratio untuk tahun 2011-2017 menunjukkan bahwa rata-rata DOL yang dicapai oleh perusahaan sebesar rata-rata pertahun sebesar $127 \%$. Hal ini mengindikasikan bahwa kemampuan perusahaan dalam memperoleh aktiva lancar selalu dapat menutupi hutangnya

\section{d. Variabel Rentabilitas (Y)}

Dalam kaitannya dengan rentabilitas, hal yang perlu diperoleh terlebiuh dahulu adalah direntabilitas sekonomi dan rentabilitas modal sendiri. Bedasarkan hasil perhitungan disajikan data sebagai berikut:

\begin{tabular}{|c|c|c|c|}
\hline \multicolumn{4}{|c|}{ Tabel 5. Hasil Perhitungan Rentabilitas } \\
Tahun & $\begin{array}{c}\text { Rentabilitas } \\
\text { Ekonomi (\%) }\end{array}$ & $\begin{array}{c}\text { Rentabilitas } \\
\text { Modal Sendiri } \\
\text { (\%) }\end{array}$ & $\begin{array}{c}\text { Rata-rata } \\
\text { Rentabilitas } \\
\text { Perusahaan } \\
\text { (\%) }\end{array}$ \\
\hline 2011 & $(0,14)$ & 1,00 & 0,43 \\
\hline 2012 & 0,07 & 1,00 & 0,53 \\
\hline 2013 & 0,02 & 1,00 & 0,51 \\
\hline 2014 & 0,02 & 1,00 & 0,51 \\
\hline 2015 & 0,12 & 1,00 & 0,56 \\
\hline 2016 & 0,08 & 1,00 & 0,54 \\
\hline 2017 & 0,11 & 1,00 & 0,56 \\
\hline $\begin{array}{c}\text { Rata- } \\
\text { rata }\end{array}$ & 0,04 & 1,00 & 0,52 \\
\hline \multicolumn{4}{|c|}{ Sumber : Data primer diolah } \\
\hline
\end{tabular}

Berdasarkan tabel di atas pertumbuhan rentabilitas perusahaan berfluktuatif dengan 
rata-rata sebesar 0,52\%. Pertumbuhan kenaikan tertinggi dicapai pada tahun 2015 dan 2017 yang mencapai $0,56 \%$, sedangkan pertumbuhan terendah dialami tahun 2011 yang hanya mencapai $0,43 \%$. Penurunan dan peningkatan ini disebabkan karena laba operasional yang juga fluktuatif.

\section{Pengujian Asumsi Klasik}

\section{Uji Normalitas}

Uji normalitas dilakukan untuk menguji apakah dalam model regresi, variabel dependen dan variabel independen berdistribusi normal atau berdistribusi tidak normal. Berikut ini Hasil uji normalitas dengan alat uji KolmogorovSmirnov Test, sebagai berikut:

\begin{tabular}{|c|c|c|c|c|c|c|}
\hline \multicolumn{7}{|c|}{$\begin{array}{l}\text { Tabel 6. Hasil Normalitas Dengan } \\
\text { Kolmogorov-Smirnov Test }\end{array}$} \\
\hline & \multicolumn{3}{|c|}{$\begin{array}{l}\text { Kolmogorov- } \\
\text { Smirnov }^{\mathrm{a}}\end{array}$} & \multicolumn{3}{|c|}{ Shapiro-Wilk } \\
\hline & Statistic & Df & Sig. & Statistic & df & Sig. \\
\hline Rentabilitas $(Y)$ & .269 & 7 & .136 & .840 & 7 & .099 \\
\hline
\end{tabular}

Berdasarkan hasil pengujian pada tabel di atas, diperoleh nilai signifikansi $\alpha=0,136$ dimana nilai tersebut lebih besar dari nilai $\alpha=$ 0,050 atau $(0,136>0,05)$. Dengan demikian maka asumsi distribusi persamaan pada uji ini adalah normal.

\section{Uji Multikonilieritas}

Pengujian mutlikolinearitas dilakukan untuk meyakini bahwa antar variabel bebas tidak memiliki multikolinearitas atau tidak memiliki hubungan korelasi antara variabel yang ditetapkan sebagai model dalam penelitian, karena model regresi yang baik seharusnya tidak terjadi korelasi di antara variabel independen. Uji multikolinearitas dilakukan dengan melihat nilai Tolerance Value dan Variance Inflation Factor (VIF). Adapun hasil pengujiannya sebagai berikut:

\begin{tabular}{|l|c|c|}
\hline \multicolumn{3}{|c|}{$\begin{array}{c}\text { Tabel 7. Hasil Uji Multikolinieritas } \\
\text { Dengan Collinierity Statistic }\end{array}$} \\
\cline { 2 - 3 } \multicolumn{1}{|c}{ Model } & Collinearity Statistics \\
\cline { 2 - 3 } & Tolerance & VIF \\
\hline 1 (Constant) & & 1.046 \\
\hline $\mathrm{DFL}\left(\mathrm{X}_{1}\right)$ & .956 & 1.052 \\
\hline $\mathrm{DOL}\left(\mathrm{X}_{2}\right)$ & .951 & 1.028 \\
\hline $\mathrm{CR}\left(\mathrm{X}_{3}\right)$ & .983 & Sumber: Data diolah \\
\hline \multicolumn{2}{|c}{} \\
\hline
\end{tabular}

Berdasarkan hasil pengujian pada tabel di atas, nilai tolerance masing-masing variabel bebas $<1,0$ dan nilai Variance Inflation Factor (VIF) sebesar $<10$, dengan demikian model regresi ini tidak ada multikolinearitas.

\section{Uji Heteroskesdastisitas}

Pengujian heteroskedastisitas dimaksudkan untuk menguji apakah dalam sebuah model regresi terjadi ketidaksamaan varians residual. Salah satu cara untuk mendeteksi ada tidaknya heteroskedastisitas adalah dengan uji scater plot. Adapun hasil nya sebagai berikut:

Scatterplot

Dependent Variable: Rentabilitas $(M$

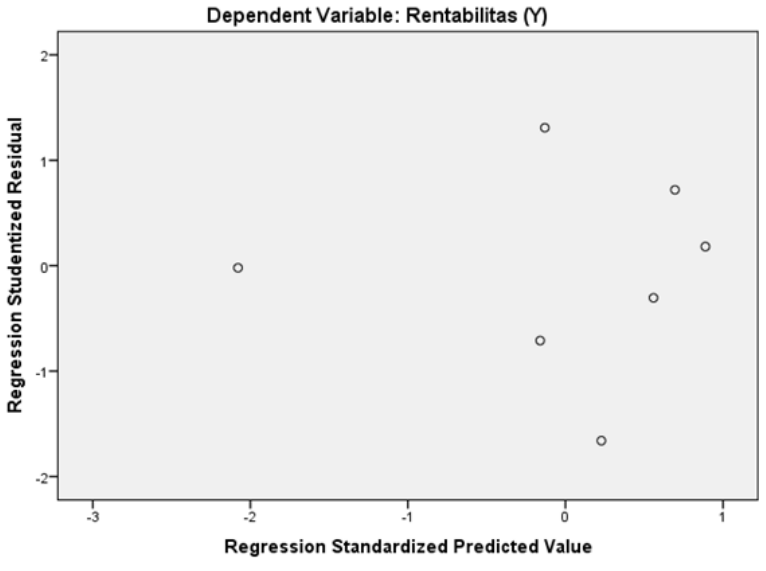

Gambar 1 Hasil Uji Heteroskedastisitas

Berdasarkan gambar di atas, disimpulkan tidak terdapat gangguan heteroskedastisitas, hal ini dibuktikan dengan titik-titik pada grafik scatter plot tidak mempunyai pola penyebaran yang jelas dan titik-titik tersebut menyebar di atas dan dibawah angka 0 (nol) pada sumbu Y.

\section{Hasil Analisis Data}

Pada bagian pengujian ini dimaksudkan untuk menunjukkan hasil dari pengujian atas variabel DFL $\left(\mathrm{X}_{1}\right)$ dan Degree Operating Leverage (DOL) $\left(\mathrm{X}_{2}\right)$ Terhadap Rentabilitas (Y). Adapun hasil analisis dalam penelitian ini sebagai berikut:

\section{Analisis Regresi Linier Sederhana}

Uji regresi linier sederhana ini dimaksudkan untuk mengetahui seberapa besar pengaruh variabel $\mathrm{DFL}\left(\mathrm{X}_{1}\right)$ dan Degree Operating Leverage (DOL) $\left(\mathrm{X}_{2}\right)$ terhadap Rentabilitas $(\mathrm{Y})$ secara sendiri-sendiri. Adapun hasil analisis regresi linier sederhana sebagai berikut Berdasarkan perhitungan regresi berganda menggunakan program IBM SPSS (Statistical Program for Social Science) versi 24.00 for windows, 
diperoleh hasil sebagai berikut :

\begin{tabular}{|c|c|c|c|c|c|}
\hline \multicolumn{6}{|c|}{$\begin{array}{l}\text { Tabel 10. Hasil Uji Regresi Lini } \\
\text { Antara DFL }\left(X_{1}\right) \text { Terhadap Ren }\end{array}$} \\
\hline \multicolumn{6}{|c|}{ Coefficients ${ }^{\mathrm{a}}$} \\
\hline \multirow[b]{2}{*}{ Model } & \multicolumn{2}{|c|}{$\begin{array}{l}\text { Unstandardized } \\
\text { Coefficients }\end{array}$} & \multicolumn{3}{|c|}{ Standardized Coefficients } \\
\hline & B & Std. Error & Beta & $\mathbf{t}$ & Sig. \\
\hline 1 (Constant) & .548 & .018 & & 30.436 & .000 \\
\hline $\operatorname{DFL}\left(X_{1}\right)$ & -.014 & .006 & -.709 & -2.248 & .074 \\
\hline
\end{tabular}

Dari hasil perhitungan pada tabel di atas dapat disajikan ke dalam bentuk persamaan regresi standardized: $\mathbf{Y}=\mathbf{0 , 5 4 8}-\mathbf{0 , 0 1 4 X _ { 1 }}$

Adapun persamaan tersebut dapat dijelaskan sebagai berikut :

a. Konstanta sebesar 0,548, menyatakan bahwa tanpa dipengaruhi variabel DFL maka besarnya nilai rentabilitas sudah terbentuk sebesar 0,548.

b. Variabel DFL $\left(\mathrm{X}_{1}\right)$ berpengaruh negatif terhadap rentabilitas (Y) dengan nilai koefisien sebesar -,014, yang artinya jika variabel DFL $\left(\mathrm{X}_{1}\right)$ meningkat satu satuan dengan asumsi variabel lain tetap, maka rentabilitas akan mengalami penurunan sebesar -0,014satuan.

\begin{tabular}{|c|c|c|c|c|c|}
\hline \multirow{2}{*}{\multicolumn{6}{|c|}{\begin{tabular}{|c|} 
Tabel 11. Hasil Uji Regresi Linier Seder \\
Operating Leverage (DOL) $\left(\mathrm{X}_{2}\right)$ Terha \\
Coefficients
\end{tabular}}} \\
\hline & & & & & \\
\hline \multirow[b]{2}{*}{ Model } & \multicolumn{2}{|c|}{$\begin{array}{l}\text { Unstandardized } \\
\text { Coefficients }\end{array}$} & \multicolumn{3}{|c|}{ Standardized Coefficients } \\
\hline & B & Std. Error & Beta & $t$ & Sig. \\
\hline 1 (Constant) & .529 & .024 & & 21.922 & .000 \\
\hline $\operatorname{DOL}\left(X_{2}\right)$ & .001 & .000 & -.237 & -.546 & .608 \\
\hline
\end{tabular}

Dari hasil perhitungan pada tabel di atas dapat disajikan ke dalam bentuk persamaan regresi standardized: $\mathbf{Y}=\mathbf{0 , 5 2 9}+\mathbf{0 , 0 0 1 X _ { 2 }}$

Adapun persamaan tersebut dapat dijelaskan sebagai berikut :

a. Konstanta sebesar 0,529, menyatakan bahwa tanpa dipengaruhi variabel Degree Operating Leverage (DOL), maka besarnya nilai rentabilitas sudah terbentuk sebesar 0,529 .

b. Variabel Degree Operating Leverage (DOL) $\left(\mathrm{X}_{2}\right)$ berpengaruh positif terhadap rentabilitas (Y) dengan nilai koefisien sebesar 0,001 . Yang artinya jika variabel Degree Operating Leverage (DOL) $\left(\mathrm{X}_{2}\right)$ meningkat satu satuan dengan asumsi variabel lain tetap, maka rentabilitas akan meningkat sebesar 0,001 satuan. Pengaruh tersebut positif namun tidak signifikan.

\begin{tabular}{|c|c|c|c|c|c|}
\hline \multirow{2}{*}{\multicolumn{6}{|c|}{$\begin{array}{r}\text { Tabel 11. Hasil Uji Regresi Linier Sede } \\
\text { Ratio }(\text { CR })\left(X_{3}\right) \text { Terhadap Rer } \\
\text { Coefficients }^{\mathrm{a}}\end{array}$}} \\
\hline & & & & & \\
\hline \multirow[b]{2}{*}{ Model } & \multicolumn{2}{|c|}{$\begin{array}{l}\text { Unstandardized } \\
\text { Coefficients }\end{array}$} & \multicolumn{3}{|c|}{ Standardized Coefficients } \\
\hline & B & Std. Error & Beta & $t$ & Sig. \\
\hline 1 (Constant) & .404 & .073 & & 5.556 & .003 \\
\hline $\mathrm{CR}\left(\mathrm{X}_{3}\right)$ & .092 & .056 & .589 & 1.631 & .164 \\
\hline
\end{tabular}

Dari hasil perhitungan pada tabel di atas dapat disajikan ke dalam bentuk persamaan regresi standardized: $\mathbf{Y}=\mathbf{0 , 4 0 4}+\mathbf{0 , 0 9 2} \mathrm{X}_{2}$

Adapun persamaan tersebut dapat dijelaskan sebagai berikut :

a. Konstanta sebesar 0,404, menyatakan bahwa tanpa dipengaruhi variabel Curren Ratio (CR), maka besarnya nilai rentabilitas sudah terbentuk sebesar 0,404.

b. Variabel Curren Ratio (CR) $\left(\mathrm{X}_{3}\right)$ berpengaruh positif terhadap rentabilitas (Y) dengan nilai koefisien sebesar 0,092. Yang artinya jika variabel Curren Ratio (CR) $\left(\mathrm{X}_{3}\right)$ meningkat satu satuan dengan asumsi variabel lain tetap, maka rentabilitas akan meningkat sebesar 0,092 satuan. Pengaruh tersebut positif namun tidak signifikan.

\section{Analisis Regresi Berganda}

Analisis regresi berganda dimaksudkan untuk mengetahui seberapa besar pengaruh variabel DFL $\left(\mathrm{X}_{1}\right)$ dan Degree Operating Leverage (DOL) $\left(\mathrm{X}_{2}\right)$ terhadap rentabilitas $(\mathrm{Y})$. Berdasarkan perhitungan regresi berganda menggunakan program IBM SPSS (Statistical Program for Social Science) versi 22.00 for windows, diperoleh hasil sebagai berikut :

\begin{tabular}{|l|r|r|r|r|r|}
\hline \multicolumn{5}{|c|}{ Tabel 12. Hasil Uji Regresi Berganda } \\
\hline \multirow{4}{*}{ Model } & \multicolumn{1}{|c|}{$\begin{array}{c}\text { Unstandardized } \\
\text { Coefficients }\end{array}$} & \multicolumn{2}{|c|}{ Standardized Coefficients } \\
\cline { 2 - 7 } & \multicolumn{1}{|c|}{ B } & Std. Error & Beta & \multicolumn{1}{c|}{$\mathbf{t}$} & \multicolumn{1}{c|}{ Sig. } \\
\hline $1($ Constant) & .422 & .031 & & 13.728 & .001 \\
\hline $\mathrm{DFL}\left(\mathrm{X}_{1}\right)$ & -.015 & .003 & -.765 & -5.126 & .014 \\
\hline $\mathrm{DOL}\left(\mathrm{X}_{2}\right)$ & -2.408 & .000 & -.025 & -.170 & .876 \\
\hline $\mathrm{CR}\left(\mathrm{X}_{3}\right)$ & .102 & .023 & .657 & 4.440 & .021 \\
\hline & \multicolumn{5}{|c|}{ Sumber : Data primer diolah } \\
\hline
\end{tabular}


Berdasarkan hasil perhitungan pada tabel di atas dapat disajikan ke dalam bentuk persamaan regresi standardized sebagai berikut:

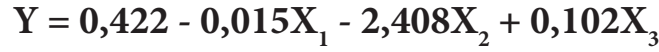

Keterangan:

$\mathrm{Y}=$ Variabel Rentabilitas

$\mathrm{X}_{1}=$ Variabel Degree Financing Leverage (DFL)

$\mathrm{X}_{2}=$ Variabel Degree Operating Leverage (DOL)

$\mathrm{X}_{3}=$ Variabel Current Ratio $(\mathrm{CR})$

Adapun persamaan tersebut dapat dijelaskan sebagai berikut:

a. Nilai konstanta diperoleh sebesar 0,422, menyatakan bahwa tanpa dipengaruhi oleh variabel DFL $\left(\mathrm{X}_{1}\right)$, DOL $\left(\mathrm{X}_{2}\right)$ dan $\mathrm{CR}\left(\mathrm{X}_{3}\right)$ besarnya nilai rentabilitas sudah terbentuk sebesar 0,422 .

b. Variabel DFL $\left(\mathrm{X}_{1}\right)$ berpengaruh negatif dan signifikan terhadap rentabilitas (Y) dengan nilai koefisien sebesar -0,015. Hal ini diartikan bahwa jika variabel DFL $\left(\mathrm{X}_{1}\right)$ meningkat satu satuan dengan asumsi variabel DOL $\left(\mathrm{X}_{2}\right)$ dan $\mathrm{CR}\left(\mathrm{X}_{3}\right)$ tetap atau konstan (0), maka rentabilitas (Y) akan mengalami penurunan -0,015.

c. Variabel DOL (X2) berpengaruh negatif dan signifikan terhadap rentabilitas (Y) dengan nilai koefisien sebesar -2,408. Hal ini diartikan bahwa jika variabel DOL $\left(\mathrm{X}_{2}\right)$ meningkat satu satuan dengan asumsi variabel DFL $\left(\mathrm{X}_{1}\right)$ dan $\mathrm{CR}\left(\mathrm{X}_{3}\right)$ tetap atau konstan (0), maka rentabilitas (Y) akan mengalami penurunan sebesar -2,408.

d. Variabel CR $\left(\mathrm{X}_{3}\right)$ berpengaruh positif dan signifikan terhadap rentabilitas (Y) dengan nilai koefisien sebesar 0,102 . Hal ini diartikan bahwa jika variabel CR $\left(\mathrm{X}_{3}\right)$ meningkat satu satuan dengan asumsi variabel DFL $\left(\mathrm{X}_{1}\right)$ dan DOL $\left(\mathrm{X}_{2}\right)$ tetap atau konstan (0), maka rentabilitas (Y) juga akan mengalami peningkatan sebesar 0,102 .

\section{Analisis Koefisien Korelasi}

Analisis koefisien korelasi (R) digunakan untuk mengetahui tingkat kekuatan hubungan atau pengaruh dari variabel bebas terhadap variabel terikat, dalam hal ini adalah variabel DFL (X1), DOL (X2) dan CR (X3) baik secara parsial maupun secara bersama-sama terhadap rentabilitas. Adapun hasil pengolahan data dapat dijelaskan sebagai berikut :

\begin{tabular}{|c|c|c|c|}
\hline \multicolumn{4}{|c|}{$\begin{array}{l}\text { Tabel 13. Hasil Uji Koefisien Korelasi Pengaruh Degree } \\
\text { Financing Leverage (DFL) }\left(\mathrm{X}_{1}\right) \text { Terhadap Rentabilitas }(\mathrm{Y})\end{array}$} \\
\hline \multicolumn{4}{|c|}{ Coefficients $^{\mathrm{a}}$} \\
\hline & & $\operatorname{DFL}\left(X_{1}\right)$ & Rentabilitas $(Y)$ \\
\hline \multirow{2}{*}{$\operatorname{DFL}\left(X_{1}\right)$} & Pearson Correlation & 1 & -709 \\
\hline & Sig. (2-tailed) & & .074 \\
\hline \multirow{2}{*}{ Rentabilitas $(Y)$} & Pearson Correlation & -.709 & 1 \\
\hline & Sig. (2-tailed) & .074 & \\
\hline \multicolumn{4}{|c|}{ Sumber : Data primer diolah } \\
\hline
\end{tabular}

Berdasarkan hasil pada tabel di atas diperoleh nilai korelasi sebesar -0,709. Hal ini menunjukkan bahwa variabel DFL $\left(\mathrm{X}_{1}\right)$ secara parsial memiliki tingkat hubungan yang kuat namun negatif terhadap rentabilitas $(\mathrm{Y})$.

\begin{tabular}{|c|c|c|c|}
\hline \multicolumn{4}{|c|}{$\begin{array}{l}\text { Tabel 14. Hasil Uji Koefisien Korelasi Pengaruh Degree } \\
\text { Operating Leverage (DOL) }\left(\mathrm{X}_{2}\right) \text { Terhadap Rentabilitas }(\mathrm{Y})\end{array}$} \\
\hline \multicolumn{4}{|c|}{ Coefficients $^{\mathrm{a}}$} \\
\hline & & $\operatorname{DOL}\left(X_{2}\right)$ & Rentabilitas $(Y)$ \\
\hline \multirow{2}{*}{$\operatorname{DOL}\left(X_{2}\right)$} & Pearson Correlation & 1 & -.237 \\
\hline & Sig. (2-tailed) & & .608 \\
\hline \multirow{2}{*}{ Rentabilitas (Y) } & Pearson Correlation & -.237 & 1 \\
\hline & Sig. (2-tailed) & .608 & \\
\hline \multicolumn{4}{|c|}{ Sumber : Data primer diola } \\
\hline
\end{tabular}

Berdasarkan hasil pada tabel di atas diperoleh nilai korelasi sebesar $-0,237$. Hal ini menunjukkan bahwa variabel DOL $\left(\mathrm{X}_{2}\right)$ secara parsial memiliki tingkat hubungan yang sedang namun negative terhadap rentabilitas $(\mathrm{Y})$.

\begin{tabular}{|c|c|c|c|}
\hline \multicolumn{4}{|c|}{$\begin{array}{l}\text { Tabel 14. Hasil Uji Koefisien Korelasi Pengaruh Current } \\
\text { Ratio }\left(\mathrm{X}_{3}\right) \text { Terhadap Rentabilitas }(\mathrm{Y})\end{array}$} \\
\hline \multicolumn{4}{|c|}{ Coefficients $^{\mathrm{a}}$} \\
\hline & & $\mathrm{CR}\left(\mathrm{X}_{3}\right)$ & Rentabilitas $(Y)$ \\
\hline \multirow{2}{*}{$\operatorname{CR}\left(X_{3}\right)$} & Pearson Correlation & 1 & .589 \\
\hline & Sig. (2-tailed) & & .164 \\
\hline \multirow{2}{*}{ Rentabilitas $(Y)$} & Pearson Correlation & .589 & 1 \\
\hline & Sig. (2-tailed) & .164 & \\
\hline \multicolumn{4}{|c|}{ Sumber : Data primer diolar } \\
\hline
\end{tabular}

Berdasarkan hasil pada tabel di atas diperoleh nilai korelasi sebesar 0486. Hal ini menunjukkan bahwa variabel $\mathrm{CR}\left(\mathrm{X}_{3}\right)$ secara parsial memiliki tingkat hubungan positif dan sedang terhadap rentabilitas (Y).

\begin{tabular}{|c|r|r|r|r|}
\hline \multicolumn{5}{|c|}{$\begin{array}{c}\text { Tabel 15. Hasil Uji Koefisien Korelasi Pengaruh DFL } \\
\left(X_{1}\right) \text {, DOL }\left(X_{2}\right) \text { dan CR }\left(X_{3}\right) \text { secara simultan Terhadap } \\
\text { Rentabilitas }(Y)\end{array}$} \\
\hline \multicolumn{5}{|c|}{ Model Summary } \\
\hline Model & R & R Square & Adjusted R Square & $\begin{array}{r}\text { Std. Error of } \\
\text { the Estimate }\end{array}$ \\
\hline 1 & $.967^{3}$ & .936 & .872 & .016 \\
\hline \multicolumn{7}{|c|}{ Sumber : Data primer diolah } \\
\hline
\end{tabular}


Berdasarkan hasil pada tabel di atas diperoleh nilai korelasi sebesar 0,967. Hal ini menunjukkan bahwa variabel DFL $\left(\mathrm{X}_{1}\right)$, DOL $\left(\mathrm{X}_{2}\right)$ dan $\mathrm{CR}\left(\mathrm{X}_{3}\right)$ secara simultan memiliki tingkat hubungan yang sangat kuat terhadap rentabilitas $(\mathrm{Y})$.

\section{Analisis Koefisien Determinasi}

Analisis koefisien deteminasi digunakan untuk mengetahui kontribusi besarnya pengaruh antara variabel bebas terhadap variabel terikat, dalam hal ini adalah variabel DFL $\left(\mathrm{X}_{1}\right)$, DOL $\left(\mathrm{X}_{2}\right)$ dan CR $\left(\mathrm{X}_{3}\right)$ baik secara parsial maupun secara bersama-sama terhadap rentabilitas. Adapun hasil pengolahan data dapat dijelaskan sebagai berikut :

\begin{tabular}{|c|c|c|c|c|}
\hline \multicolumn{5}{|c|}{$\begin{array}{l}\text { Tabel 16. Hasil Uji Koefisien Determinasi Pengaruh Degree } \\
\text { Financing Leverage }(\mathrm{DFL})\left(\mathrm{X}_{1}\right) \text { Terhadap Rentabilitas }(\mathrm{Y})\end{array}$} \\
\hline \multicolumn{5}{|c|}{ Model Summary } \\
\hline Model & $\mathbf{R}$ & R Square & Adjusted R Square & $\begin{array}{l}\text { Std. Error of } \\
\text { the Estimate }\end{array}$ \\
\hline 1 & $.709^{a}$ & .503 & .403 & .035 \\
\hline \multicolumn{5}{|c|}{ Sumber : Data primer diolah } \\
\hline
\end{tabular}

Berdasarkan hasil pada tabel di atas dapat dilihat bahwa nilai $R$ Square sebesar 0,503 atau $50,3 \%$. Hal ini menunjukkan bahwa pengaruh DFL $\left(\mathrm{X}_{1}\right)$ secara parsial terhadap rentabilitas adalah sebesar $50,3 \%$, sedangkan sisanya sebesar $49,7 \%$ dipengaruhi oleh faktor lain yang tidak diteliti.

\begin{tabular}{|c|c|c|c|c|}
\hline \multicolumn{5}{|c|}{$\begin{array}{l}\text { Tabel 17. Hasil Uji Determinasi Pengaruh Degree Operating } \\
\text { Leverage }(\mathrm{DOL})\left(\mathrm{X}_{2}\right) \text { Terhadap Rentabilitas }(\mathrm{Y})\end{array}$} \\
\hline \multicolumn{5}{|c|}{ Model Summary } \\
\hline Model & $\mathbf{R}$ & R Square & Adjusted R Square & $\begin{array}{l}\text { Std. Error of } \\
\text { the Estimate }\end{array}$ \\
\hline 1 & $.237^{\mathrm{a}}$ & .056 & -.132 & .048 \\
\hline
\end{tabular}

Berdasarkan hasil pada tabel di atas dapat dilihat bahwa nilai $R$ Square sebesar 0,056 atau $5,6 \%$. Hal ini menunjukkan bahwa pengaruh DOL $\left(\mathrm{X}_{2}\right)$ secara parsial terhadap rentabilitas adalah sebesar $5,6 \%$, sedangkan sisanya sebesar $94,4 \%$ dipengaruhi oleh faktor lain yang tidak diteliti.

\begin{tabular}{|l|r|r|r|r|}
\hline \multicolumn{5}{|c|}{ Tabel 17. Hasil Uji Determinasi Pengaruh CR $\left(\mathbf{X}_{2}\right)$} \\
Terhadap Rentabilitas $(\mathrm{Y})$ \\
\hline Model & \multicolumn{1}{|c|}{$\mathbf{R}$} & \multicolumn{1}{|c|}{ R Square } & Adjusted R Square & $\begin{array}{r}\text { Std. Error of } \\
\text { the Estimate }\end{array}$ \\
\hline 1 & $.589^{\mathrm{a}}$ & .347 & .217 & .040 \\
\hline \multicolumn{6}{|c|}{ Sumber : Data primer diolah } \\
\hline
\end{tabular}

Berdasarkan hasil pada tabel di atas dapat dilihat bahwa nilai $R$ Square sebesar 0,347 atau $34,7 \%$. Hal ini menunjukkan bahwa pengaruh CR $\left(\mathrm{X}_{3}\right)$ secara parsial terhadap rentabilitas adalah sebesar $34,7 \%$, sedangkan sisanya sebesar 65,3\% dipengaruhi oleh faktor lain yang tidak diteliti.

\begin{tabular}{|c|c|c|c|c|}
\hline \multicolumn{5}{|c|}{$\begin{array}{l}\text { Tabel 18. Hasil Uji Koefisien Determinasi Pengaruh DFL }\left(X_{1}\right) \text {, } \\
\text { DOL }\left(X_{2}\right) \text { dan CR }\left(X_{3}\right) \text { Terhadap Rentabilitas }(Y)\end{array}$} \\
\hline \multicolumn{5}{|c|}{ Model Summary } \\
\hline Model & $\mathbf{R}$ & R Square & Adjusted R Square & $\begin{array}{l}\text { Std. Error of } \\
\text { the Estimate }\end{array}$ \\
\hline 1 & $.967^{\mathrm{a}}$ & .936 & .872 & .016 \\
\hline
\end{tabular}

Berdasarkan hasil pada tabel di atas dapat dilihat bahwa nilai R Square sebesar 0,936 atau 93,6\%. Hal ini menunjukkan bahwa pengaruh DFL (X1), DOL (X2) dan CR (X3) secara bersama-sama terhadap rentabilitas (Y) adalah sebesar 93,6\%, sedangkan sisanya sebesar $6,4 \%$ dipengaruhi oleh faktor lain yang tidak diteliti.

\section{Pengujian Hipotesis}

Pengujian hipotesis dimaksudkan untuk menetukan apakah sebaiknya hipotesis diterima atau ditolak. Dalam pengujian ini digunakan uji $\mathrm{t}$ (parsial) dan uji F (Simultan).

\section{a. Uji Hipotesis Parsial (Uji t)}

Pengujian hipotesis secara parsial menggunakan uji $t$ yaitu untuk menguji bagaimana pengaruh masing-masing variabel bebas secara sendiri-sendiri terhadap variabel terikatnya.

Hipotesis Pertama : Terdapat pengaruh positif dan signifikan antara DFL terhadap rentabilitas.

\begin{tabular}{|c|c|c|c|c|c|}
\hline \multicolumn{6}{|c|}{$\begin{array}{l}\text { Tabel 19. Pengujian Hipotesis Variabel DFL }\left(X_{1}\right) \\
\text { Terhadap Rentabilitas }(Y)\end{array}$} \\
\hline \multicolumn{6}{|c|}{ Coefficients $^{\mathrm{a}}$} \\
\hline \multirow[b]{2}{*}{ Model } & \multicolumn{2}{|c|}{$\begin{array}{l}\text { Unstandardized } \\
\text { Coefficients }\end{array}$} & \multicolumn{3}{|c|}{ Standardized Coefficients } \\
\hline & B & Std. Error & Beta & $t$ & Sig. \\
\hline 1 (Constant) & .548 & .018 & & 30.436 & .000 \\
\hline $\mathrm{DFL}\left(X_{1}\right)$ & -.014 & .006 & -.709 & -2.248 & .074 \\
\hline
\end{tabular}

Berdasarkan hasil pengolahan data di atas, diperoleh nilai $\mathrm{t}_{\text {hitung }}<\mathrm{t}_{\text {tabel }}$ atau $(-2,248<2,576)$, hal itu juga diperkuat dengan signifikansi 0,074 $>0,05$. Dengan demikian hipotesis pertama yang menyatakan terdapat pengaruh positif dan signifikan antara DFL terhadap rentabilitas ditolak. 
Hipotesis Kedua : Terdapat pengaruh positif dan signifikan antara DOL terhadap rentabilitas.

\begin{tabular}{|c|c|c|c|c|c|}
\hline \multicolumn{6}{|c|}{$\begin{array}{l}\text { Tabel 20. Pengujian Hipotesis Variabel DOL }\left(X_{2}\right) \\
\text { Terhadap Rentabilitas }(Y)\end{array}$} \\
\hline \multicolumn{6}{|c|}{ Coefficients ${ }^{a}$} \\
\hline \multirow[b]{2}{*}{ Model } & \multicolumn{2}{|c|}{$\begin{array}{l}\text { Unstandardized } \\
\text { Coefficients }\end{array}$} & \multicolumn{3}{|c|}{ Standardized Coefficients } \\
\hline & B & Std. Error & Beta & $t$ & Sig. \\
\hline 1 (Constant) & .529 & .024 & & 21.922 & .000 \\
\hline $\operatorname{DOL}\left(X_{2}\right)$ & .001 & .000 & -.237 & -.546 & .608 \\
\hline \multicolumn{6}{|c|}{ Sumber : Data primer diolah } \\
\hline
\end{tabular}

Berdasarkan hasil pengolahan data di atas, diperoleh nilai $\mathrm{t}_{\text {hitung }}<\mathrm{t}_{\text {tabel }}$ atau $(-0,546<2,576)$, hal itu juga diperkuat dengan signifikansi 0,608 $>0,05$. Dengan demikian hipotesis kedua yang menyatakan terdapat pengaruh positif dan signifikan antara DOL terhadap rentabilitas ditolak.

Hipotesis Ketiga: Terdapat pengaruh positif dan signifikan antara CR terhadap rentabilitas.

\begin{tabular}{|c|c|c|c|c|c|}
\hline \multicolumn{6}{|c|}{$\begin{array}{l}\text { Tabel 20. Pengujian Hipotesis Variabel CR }\left(\mathrm{X}_{3}\right) \\
\text { Terhadap Rentabilitas }(Y)\end{array}$} \\
\hline \multicolumn{6}{|c|}{ Coefficients $^{\mathrm{a}}$} \\
\hline \multirow[b]{2}{*}{ Model } & \multicolumn{2}{|c|}{$\begin{array}{l}\text { Unstandardized } \\
\text { Coefficients }\end{array}$} & \multicolumn{3}{|c|}{ Standardized Coefficients } \\
\hline & B & Std. Error & Beta & $t$ & Sig. \\
\hline 1 (Constant) & .404 & .073 & & 5.556 & .003 \\
\hline $\operatorname{CR}\left(X_{3}\right)$ & .092 & .056 & .589 & 1.631 & .164 \\
\hline
\end{tabular}

Berdasarkan hasil pengolahan data di atas, diperoleh nilai $\mathrm{t}_{\text {hitung }}<\mathrm{t}_{\text {tabel }}$ atau $(1,631<2,576)$, hal itu juga diperkuat dengan signifikansi 0,164 $>0,05$. Dengan demikian hipotesis ketiga yang menyatakan terdapat pengaruh positif dan signifikan antara CR terhadap rentabilitas ditolak.

\section{b. Uji Hipotesis Secara Simultan (Uji F)}

Pengujian hipotesis secara simultan dimaksudkan untuk mengetahui pengaruh semua variabel bebas terhadap variabel terikat yaitu DFL, DOL dan CR terhadap rentabilitas. Dalam pengujian ini digunakan uji $\mathrm{F}$.

Hipotesis Keempat : Terdapat pengaruh positif dan signifikan antara DFL $\left(\mathrm{X}_{1}\right), \mathrm{DOL}$ $\left(\mathrm{X}_{2}\right)$ dan $\mathrm{CR}\left(\mathrm{X}_{3}\right)$ secara simultan terhadap rentabilitas $(\mathrm{Y})$.

Adapun hasil pengujiannya sebagai berikut:

\begin{tabular}{|l|r|r|r|r|r|}
\hline \multicolumn{7}{|c|}{ Tabel 21. Pengujian Hipotesis Secara Simultan } \\
\hline \multicolumn{1}{|c|}{ Model } & $\begin{array}{c}\text { Sum of } \\
\text { Squares }\end{array}$ & df & $\begin{array}{c}\text { Mean } \\
\text { Square }\end{array}$ & F & Sig. \\
\hline 1 Regression & .011 & 3 & .004 & 14.634 & $.027^{\mathrm{b}}$ \\
\hline Residual & .001 & 3 & .000 & & \\
\hline Total & .012 & 6 & & & \\
\hline \multicolumn{7}{|c|}{ Sumber : Data primer diolah } \\
\hline
\end{tabular}

Berdasarkan hasil pengolahan data di atas, diperoleh nilai $\mathrm{F}_{\text {hitung }}>\mathrm{F}_{\text {tabel }}$ atau $(14,634>5,190)$, hal itu juga diperkuat dengan nilai signifikansi $0,027<0,05$. Dengan demikian hipotesis keempat yang menyatakan terdapat pengaruh positif dan signifikan antara DFL, DOL dan CR secara simultan terhadap rentabilitas dapat diterima.

\section{HASIL DAN PEMBAHASAN}

Dari hasil pengujian statistik dan analisis diatas, maka dapat dipaparkan analisis pengaruh DFL, DOL dan CR terhadap rentabilitas pada PT. Indah Kiat Pulp and Paper, Tbk, sebagai berikut :

1. Pengaruh Degree Financing Leverage (DFL) Terhadap Rentabilitas Pada PT. Indah Kiat Pulp and Paper, Tbk.

Dari hasil analisis statistik, diperoleh persamaan model regresi adalah $\mathbf{Y}=\mathbf{0 , 5 4 8}-\mathbf{0 , 0 1 4 X _ { 1 }}$. Koefisien beta memiliki nilai negatif sehingga DFL memiliki pengaruh yang negatif. Koefisien korelasi antara DFL terhadap rentabilitas adalah sebesar -0,709. Dengan demikian dapat dikatakan bahwa kedua variabel memiliki hubungan yang negatif sebesar -0,709 dengan tingkat hubungan atau pengaruh kuat.

Nilai koefisien determinasi diperoleh sebesar 0,503, data tersebut mengindikasikan bahwa variabel DFL memberikan kontribusi pengaruh sebesar $50,3 \%$ terhadap rentabilitas. Uji hipotesis diperoleh nilai $\mathrm{t}_{\text {hitung }}<\mathrm{t}_{\text {tabel }}$ atau $(-2,248$ $<2,576)$ dan signifikansi $t>0,05$ atau $(0,074$ $>0,05)$. Dengan demikian hipotesis H1 yang penulis ajukan ditolak, hal ini menunjukkan bahwa DFL berpengaruh negatif dan siginifikan terhadap rentabilitas.

\section{Pengaruh Degree Operating Leverage (DOL) Terhadap Rentabilitas Pada PT. Indah Kiat Pulp and Paper, Tbk. \\ Dari hasil analisis statistik, diperoleh persa- maan model regresi adalah $\mathrm{Y}=\mathbf{0 , 5 2 9}+\mathbf{0 , 0 1 4 X _ { 1 }}$. Konstanta memiliki nilai positif sehingga DOL}


memiliki pengaruh yang positif. Koefisien korelasi antara DOL terhadap rentabilitas adalah sebesar -0,237. Dengan demikian dapat dikatakan bahwa kedua variabel memiliki hubungan yang negatif sebesar - 0,237 dengan tingkat hubungan atau pengaruh lemah.

Nilai koefisien determinasi diperoleh sebesar 0,056, data tersebut mengindikasikan bahwa variabel DOL memberikan kontribusi pengaruh sebesar 5,6\% terhadap rentabilitas. Uji hipotesis diperoleh nilai $\mathrm{t}_{\text {hitung }}<\mathrm{t}_{\text {tabel }}$ atau $(-0,546<2,576)$ dan signifikansi $t<0,05$ atau $(0,608>0,05)$. Dengan demikian hipotesis $\mathrm{H} 2$ yang penulis ajukan ditolak, hal ini menunjukkan bahwa DOL berpengaruh negatif dan siginifikan terhadap rentabilitas.

\section{Pengaruh Current Ratio Terhadap Rentabilitas Pada PT. Indah Kiat Pulp and Paper, Tbk.}

Dari hasil analisis statistik, diperoleh persamaan model regresi adalah $\mathbf{Y}=\mathbf{0 , 4 0 4}$ $+\mathbf{0 , 0 9 2} \mathrm{X}_{3}$. Konstansta memiliki nilai positif sehingga apabila CR mengalami kenaikan maka rentabilitas juga akan meningkat. Koefisien korelasi antara CR terhadap rentabilitas adalah sebesar 0,589. Dengan demikian dapat dikatakan bahwa kedua variabel memiliki hubungan yang positif sebesar 0,589 dengan tingkat hubungan atau pengaruh yang sedang.

Nilai koefisien determinasi diperoleh sebesar 0,347, data tersebut mengindikasikan bahwa variabel CR memberikan kontribusi pengaruh sebesar $34,7 \%$ terhadap rentabilitas. Uji hipotesis diperoleh nilai $\mathrm{t}_{\text {hitung }}<\mathrm{t}_{\text {tabel }}$ atau $(1,631<$ $1,984)$ dan tidak signifikansi $t>0,05$ atau $(0,164$ $>0,05)$. Dengan demikian hipotesis H3 yang penulis ajukan ditolak, hal ini menunjukkan bahwa CR berpengaruh negatif dan siginifikan terhadap rentabilitas.

4. Pengaruh Degree Financing Leverage dan Degree Operating Leverage dan Current Ratio Secara Simultan Terhadap Rentabilitas Pada PT. Indah Kiat Pulp and Paper, Tbk.

Dari hasil analisis statistik, diperoleh persamaan model regresi adalah $\mathbf{Y}=\mathbf{0 , 4 2 2}$ -

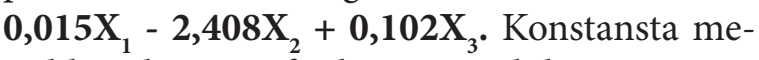
miliki nilai positif sehingga apabila DFL, DOL dan CR mengalami kenaikan, maka rentabilitas juga akan meningkat. Koefisien korelasi antara
DFL $<$ DOL dan CR secara simultan terhadap rentabilitas adalah sebesar 0,967 . Dengan demikian dapat dikatakan bahwa keempat variabel memiliki hubungan sebesar 0,967 dengan tingkat hubungan atau pengaruh sangat kuat.

Nilai koefisien determinasi diperoleh sebesar 0,936, data tersebut mengindikasikan bahwa variabel DFL, DOL dan CR secara simultan memberikan kontribusi pengaruh sebesar $93,6 \%$ terhadap rentabilitas. Uji hipotesis diperoleh nilai $\mathrm{F}_{\text {hitung }}>\mathrm{F}_{\text {tabel }}$ atau $(14,634$ $>5,190)$ dan $\mathrm{F}$ signifikansi $<0,05$ atau $(0,027$ $<0,05)$. Dengan demikian hipotesis H4 yang penulis ajukan dapat diterima, hal ini menunjukkan bahwa DFL, DOL dan CR secara simultan berpengaruh positif dan siginifikan terhadap rentabilitas.

\section{KESIMPULAN DAN SARAN \\ Kesimpulan}

Setelah penulis melakukan penelitian dan analisis mengenai pengaruh Degree Financing Leverage (DFL), Degree Operating Leverage (DOL), dan Current Ratio (CR) terhadap rentabilitas pada PT. Indah Kiat Pulp and Paper, Tbk, seperti yang telah dipaparkan pada babbab sebelumnya, maka penulis dapat menarik kesimpulan sebagai berikut:

1. Degree Financing Leverage (DFL) berpengaruh negatif dan siginifikan terhadap rentabilitas. Hal ini dapat dilihat dari Nilai $\mathrm{t}_{\text {hitung }}<\mathrm{t}_{\text {tabel }}(-2,248<2,576)$ dan signifikansi $\mathrm{t}>0,05$ atau $(0,074>0,05)$ DFL mempunyai korelasi negatif rentabilitas sebesar $-0,709$. DFL mempunyai kontribusi pengaruh sebesar 50,3\% terhadap rentabilitas. Model regresi sederhana yang diperoleh adalah $\mathbf{Y}$ $=0,548-\mathbf{0 , 0 1 4} \mathrm{X}_{1}$ yang diartikan apabila DFL yang meningkat maka akan menurunkan rentabilitas.

2. Degree Operating Leverage (DOL) berpengaruh positif namun tidak siginifikan terhadap rentabilitas. Hal ini dapat dilihat dari Nilai $\mathrm{t}_{\text {hitung }}<\mathrm{t}_{\text {tabel }}$ atau $(-0,546$ $<2,576)$ dan signifikansi $t>0,05$ atau $(0,608>0,05)$. Degree Operating Leverage (DOL) mempunyai korelasi negatif dengan rentabilitas sebesar -0,237. Degree Operating Leverage (DOL) mempunyai kontribusi pengaruh sebesar 5,6\% terhadap rentabilitas. Model regresi sederhana yang 
diperoleh adalah $\mathbf{Y}=\mathbf{0 , 5 2 9}+\mathbf{0 , 0 0 1 \mathbf { X } _ { 2 }}$ yang diartikan apabila Degree Operating Leverage (DOL) meningkat maka akan meningkatkan rentabilitas.

3. Current ratio (CR) berpengaruh positif namun tidak siginifikan terhadap rentabilitas. Hal ini dapat dilihat dari Nilai $\mathrm{t}_{\text {hitung }}$ $<\mathrm{t}_{\text {tabel }}$ atau $(1,631<2,576)$ dan signifikansi $\mathrm{t}>0,05$ atau $(0,164>0,05)$. Current Ratio (CR) mempunyai korelasi positif dengan rentabilitas sebesar 0,589. Current Ratio (CR) mempunyai kontribusi pengaruh sebesar 34,7\% terhadap rentabilitas. Model regresi sederhana yang diperoleh adalah $\mathbf{Y}$ $=0,404+0,092 \mathrm{X}_{3}$ yang diartikan apabila Current Ratio (CR) meningkat maka akan meningkatkan rentabilitas.

4. Degree Financing Leverage (DFL), Degree Operating Leverage (DOL), dan Current Ratio (CR) secara simultan berpengaruh positif dan siginifikan terhadap rentabilitas. Hal ini dapat dilihat dari Nilai $\mathrm{F}_{\text {hitung }}>$ $\mathrm{F}_{\text {tabel }}$ atau $(14,634>5,190)$ dan F signifikansi $<0,05$ atau $(0,027<0,05)$. DFL, DOL dan CR secara simultan mempunyai kontribusi $\left(\mathrm{R}^{2}\right)$ sebesar $93,6 \%$ terhadap rentabilitas, selebihnya sebesar $6,4 \%$ dipengaruhi oleh variabel lain yang tidak diteliti. Model regresi berganda yang diperoleh adalah $\mathbf{Y}=$ $0,422-0,015 X_{1}-2,408 X_{2}+0,102 X_{3}$ yang diartikan apabila DFL dan DOL mengalami peningkatan, maka rentabilitas juga akan menurun serta jika CR mengalami peningkatan maka rentabilitas akan meningkat.

\section{Saran}

1. Dalam rangka menjamin kontinuitas perusahaan, maka sebaiknya perusahaan meningkatkan modal sendiri, hal ini dimaksudkan untuk mengurangi beban bunga yang harus ditanggung oleh perusahaan.

2. Perusahaan perlu meningkatkan usahausaha yang berkaitan dengan kemampuan perusahaan dalam membayar hutang jangka pendeknya dengan mengatur penggunaan dana eksternal, dalam hal pembiayaan perusahaan tiap tahunnya, dan tetap mempertahankan modal kerja yang baik dan efisien.

3. Perusahaan perlu mengurangi penggunaan modal pinjaman, sehingga dapat mening- katkan laba operasional yang dicapai oleh perusahaan.

4. Bagipenelitilain yang melakukan penelitian yang sama, disarankan untuk meneliti faktor lain yang dapat mempengaruhi profitabilitas dan lebih berkembang dengan menambah bahasan variabel lain. Selain itu jumlah pengambilan sampel tahun yang lebih banyak serta rentang waktu penelitian yang lebih panjang akan mempretasikan kondisi secara lebih baik lagi

\section{DAFTAR PUSTAKA}

Algifari (2010), "Analisis Regresi”, Yogyakarta, 2010.

Arikunto, Suharsimi (2011)."Prosedur Penelitian Suatu Pendekatan Praktek”, PT. Rineka Cipta, Jakarta.

Assauri, Sofian (2010). "Manajemen Degree Operating Leverage (DOL)si Dan Operasi", LPFE Universitas Indonesia, Jakarta.

Faqih Nabhan, "Pengaruh leverage keuangan terhadap retur saham, pertumbuhan penjualan dan laba operasi perusahaan go public" yang terdaftar di Bursa Efek Jakarta, 2001.

G.R. Terry, \& Rue, Leslie W. Rue, (2010), "Dasardasar Manajemen”, Bumi Aksara. Jakarta.

Ghozali, Imam (2013). "Aplikasi Analisis Multivariate dengan Program SPSS”, Edisi Kelima, Badan Penerbit Undip, Semarang.

Hanafi Manduh (2004) "Analisis Laporan Keuangan", edisi revisi, cetakan pertama, Penerbit UPP AMP YKPN, Jakarta.

Hasibuan (2016), "Manajemen Sumber Daya Manusia", Haji Masagung. Jakarta.

Husnan Suad dan Enny Pudjiastuti (2004) "Dasar-Dasar Manajemen Keuangan", edisi pertama, cetakan pertama, edisi pertama, cetakan pertama, Penerbit UPP AMP YKPN, Yogyakarta.

Istijianto (2009. "Aplikasi Praktis Riset Pemasaran", Gramedia Pustaka Utama, Jakarta.

Martono dan Agus Harjito (2008)"Manajemen Keuangan", edisi pertama, cetakan ketujuh, Penerbit Ekonesia, Yogyakarta.

Munawir, S., "Analisa Laporan Keuangan", edisi ketujuh, Penerbit BPFE, Yogyakarta, 2007.

Nur Asida "Leverage keuangan terhadap laba atas modal sendiri (ROE) pada PT. Semen Tonasa. Penelitian tersebut menggunakan 
data laporan keuangan PT. Semen Tonasa Kab. Pangkep" periode 2000-2004, Pangkep, 2006.

Riyanto, Bambang, (2001) "Dasar-Dasar Pembelanjaan Perusahaan", edisi keempat, cetakan keenam, Penerbit : BPFE, Yogyakarta.

Sartono, Agus, "Manajemen Keuangan Teori dan Aplikasi", Edisi keempat, cetakan pertama, Penerbit BPFE, Yogyakarta, 2001.

Sarwono, Jonathan. 2012. "Metode Penelitian Kuantitatif Dan Kualitatif”. Graha Ilmu. Yogyakarta.

Sinuraya, Murthada, "Teori Manajemen Keuangan", edisi kedua, Penerbit Fakultas Ekonomi, Universitas Indonesia, Jakarta, 2008.

Sjahrial, Dermawan (2009) "Kumpulan Pembahasan, Soal-soal Manajemen Keungan", edisi kedua, Penerbit Mitra Wacana Media, Jakarta.

Sugiyono (2014) "Metode Penelitian Kuantitatif Kualitatif dan $R$ \& $D$ ", Penerbit CV. Alfabeta, Bandung.

Sutrisno (2003) "Manajemen Keuangan, Teori, Konsep dan Aplikasi", edisi pertama, cetakan ketiga, Penerbit : Ekonisia, Yogyakarta.

Swastha, Bashu dan T. Handoko (2010). "Manajemen Pemasaran Moderen", BPFE, Yogyakarta.

Syamsuddin, Lukman (2002) "Manajemen Keuangan Perusahaan", edisi Baru, cetakan ketujuh, Penerbit : Rajawali Pers, Jakarta.

Syofian Siregar (2010). "Statistika Deskriptif Untuk Penelitian”, PT Raja Grafindo Persada, Jakarta.

Umar, Husen (2013). "Riset Pemasaran Dan Perilaku Pelanggan”. PT. Gramedia Pustaka Utama. Jakarta.

Warsono, (2003) "Manajemen Keuangan Perusahaan", Edisi ketiga, cetakan pertama, jilid satu, Penerbit Bayu Media, Malang, 2003.

Yamit, Zulian (2001) "Manajemen Keuangan", edisi pertama, cetakan ketiga, Penerbit : Ekonisia, Yogyakarta. 